Through the lens of the ASEAN Intergovernmental Commission on Human Rights
(AICHR), this chapter considers the political impacts of ASEAN's recent reform.
Prevailing explanations of why and how ASEAN has come to govern human rights
frame this as a process of normative change. This chapter departs from these accounts
conamining the structural context in which political processes have been reformed,
highlights the AICHR's depoliticizing impacts at the level of the polity and at the level
of politics, where ASEAN's elites have been empowered as opposed to rights
advocates. The chapter argues that the AICHR gives the appearance of expanding
according to their preferences.




\section{ASEAN, Anti-Politics, and Human Rights}

\section{Kelly Gerard}

\subsection{Introduction}

The Association of Southeast Asian Nations (ASEAN) appears to be a far cry from its former self: after decades of rhetoric but limited substance on economic integration, the ASEAN Economic Community commenced in 2015 with the 'free' flow of goods and services and the 'freer' movement of labour and capital. More remarkably, however, after decades of being known as a 'club of dictators', policymakers have signalled greater political integration through commitments to the rule of law, democracy, and human rights, enshrined in pivotal agreements such as the ASEAN Charter.

These substantial reforms have entailed the expansion of ASEAN's political processes, both vertically and horizontally. Regulatory networks have been established that harmonize standards across the region, with agreed standards implemented and policed locally. The establishment of these networks has meant the vertical expansion of political processes, with new spaces of regional governance created within states 
where state actors and agencies serve as regulators to implement regional controls on domestic social and political structures. These networks govern a widening range of issues, including investment liberalization, policing, the rights of migrant workers, and seasonal smoke haze. ASEAN's reform has also entailed the horizontal expansion of political processes, with regulatory networks comprising a mix of actors from state agencies, civil society organizations, think tanks, academia, and scientific communities. This horizontal expansion constitutes a substantial shift in practice, given ASEAN elites' historical preference for a highly minimalist and exclusive form of regional governance organized through tacit agreements among leaders and closeddoor meetings. This horizontal expansion of political processes has been central to the marketing of ASEAN's reform as 'people-oriented'.

The history of ASEAN is arguably one of anti-politics by design, with the 'ASEAN Way' ensuring that power has been distributed among a very narrow set of social forces (see Jones 2012). This vertical and horizontal expansion of ASEAN's political processes raises questions regarding the form and function of these reforms, and their political impacts. Flinders and Buller (2006: 295) define depoliticization as the

\footnotetext{
${ }^{1}$ ASEAN elites first employed the term 'people-centred', and, when the ASEAN Charter was ratified in November 2007, this was revised to 'people-oriented'.
} 
tools, mechanisms, and institutions through which politicians can attempt to move in an indirect governing relationship and/or seek to persuade the demos that they can no longer be reasonably held responsible for a certain issue, policy field or specific decision.

They note the term 'depoliticization' is in fact a misnomer, given that politics remains. The form that politics takes, however, changes because of reforms to the structures within which people interact, raising questions regarding which social groups are empowered through this process, and why and how it progresses. Depoliticization does not entail taking politics out of people's interactions, but rather reorganizing how politics takes place.

This chapter examines the political impacts of the vertical and horizontal expansion of ASEAN's processes. It does this through the lens of Jessop's (2014) disambiguation of depoliticization and cognate concepts, using this framework to chart how politics has been reconfigured. Jessop puts forward a threefold characterization of the ongoing reconfiguration of relationships and interactions across the levels of the polity, politics, and policy, these being the three levels where repoliticization and depoliticization can occur. He describes the 'polity' as 'the sphere of society in which political activities occur', with its boundaries maintained so as to differentiate it from non-political spheres, such as religion, the economy, law, education, or science. Jessop delineates the level of 'politics' as the formal and informal practices that shape the 
exercise of state power. This level contrasts with the former in that the 'polity' is presumed to be relatively stable as an instituted space, while 'politics' are the dynamic and contingent activities that take place over time and across both formal and informal political spheres. Finally, the third level of 'policy' is concerned with the 'specific fields of state intervention and abstention, decisions and non-decisions, modes of intervention' (Jessop 2014: 216), with depoliticization at the level of 'policy' defined by outcomes at other levels. As summarized by Jessop, the reconfiguring of political processes can entail depoliticization and repoliticization across these three levels:

The constitution of the polity (constitutive politics) affects unevenly capacities to engage in politics (to influence, as Lasswell (1936) put it, 'who gets what, when and how'), and this in turn constrains the range of feasible policies (policy making as an art of the possible). (Jessop 2014: 208)

Jessop's threefold characterization acknowledges political reforms and their scope for depoliticization as multidirectional, co-constitutive, and dynamic: policy changes can redraw the boundaries of the polity and also reshape political practices, which may then prompt people to organize around new claims.

Identifying the directionality and impacts of political reforms requires an understanding of the configuration of power relationships across society, and the conflicts around which different social groups have organized. Considering the 
socially embedded nature of these processes also provides a means of tackling the important question raised by Fawcett and Marsh (2014): whose interests are served by the reconfiguring of political processes? Fawcett and Marsh highlight this oversight in the depoliticization literature, which focuses on questions of how interests are represented and how governments respond to them, but not on whose interests are furthered. As they note: 'acts of de-politicisation are affected by the structural context in which these decisions are taken' (Fawcett and Marsh 2014: 178). An understanding of this structural context is thus imperative in identifying the drivers of these processes and whose interests they advance.

Drawing from Jessop's disambiguation of depoliticization and cognate concepts, this chapter analyses one component of ASEAN's reform: the ASEAN Intergovernmental Commission on Human Rights (AICHR). This agency is representative of ASEAN's reorganization, entailing both the vertical and the horizontal expansions of human rights governance. Departing from prevailing explanations of why and how ASEAN has come to govern human rights that frame this as a process of normative change, this chapter examines the rescaling and restructuring of human rights governance that have accompanied the AICHR's establishment to chart the impacts of these reforms and whose interests they further. The existing literature on the AICHR is largely informed by constructivism, seeking to demonstrate the diffusion of the human rights norm from global policy arenas to 
ASEAN through norm entrepreneurs-specifically, 'Track III' actors, such as the Working Group for the Establishment of an ASEAN Human Rights Mechanism, and 'Track II' actors, such as the ASEAN-Institute of Strategic and International Studies (ISIS) network (Aviel 2000; Davies 2013b; Durbach et al. 2009; Ginbar 2010; Tan 2011). These accounts assert that ASEAN is undergoing normative change; however, the failure of regional human rights governance to advance protections indicates a case of 'partial norm socialization', where ASEAN elites have rhetorically embraced human rights but have not altered their behaviour accordingly. To explain this instance of 'partial norm socialization', some accounts point to the tensions between regional human rights protections and the existing norms of consensus decision-making and states' apparent commitment to not interfere in one another's domestic affairs-known as the non-interference norm (Tan 2011; Davies 2013b). Similarly, other accounts understand ASEAN's human rights commitments as legitimizing tools, while states' preference for existing norms renders these commitments insignificant (Katsumata 2009; Narine 2012; Davies 2013a). Common to all of these explanations is limited analysis of how the apparent acceptance of new norms relates to broader conflicts among competing social groups, and how existing norms have been deployed in practice. Invoking existing norms to explain the weakness of ASEAN's human rights commitments problematically assumes that the content of norms, whether existing or new, is fixed (Krook and True 2012). These accounts overlook the practice of norms 
and the socio-political conflicts in which these processes are embedded, including their material aspects. The adoption and promotion of a norm can advance particular interests at the expense of others and, in doing so, address, ameliorate, or marginalize conflict. $^{2}$ Central to understanding the drivers and impacts of normative change is analysis of changes to political processes and, within that, an understanding of which interests are furthered.

Acknowledging the vital question posed by Fawcett and Marsh, of whose interests are served through depoliticization, the chapter situates analysis of the AICHR's form and function in the context for which relevant decisions have been taken, examining the relationship between this new mode of governance and the conflicts it seeks to address. Recognizing that institutions structure the form that politics can take by making particular forms of political participation acceptable and others not, the chapter examines the context in which the AICHR was established so as to chart how conflicts are expressed, mediated, or marginalized through this new mode of governance, and whose interests it advances. The chapter argues that the AICHR functions as a new target for human rights activists, giving the appearance of

\footnotetext{
${ }^{2}$ In the case of the non-intervention norm, Jones (2012) demonstrates how the scholarly consensus over ASEAN's apparent commitment to sovereignty has served to obscure the manner in which this norm has been deployed, and how elites have selectively invoked it to advance their interests.
} 
expanding rights protections while ensuring that conflicts can be managed according to the interests of ASEAN elites. The chapter develops this argument by charting the AICHR's depoliticizing impacts on, first, the level of the polity, and, second, the level of politics.

On the AICHR's depoliticizing impacts at the level of the polity, or its constitutive impacts, the chapter highlights two means through which this reconfiguring of human rights governance has empowered ASEAN elites. First, with the AICHR's establishment, ASEAN elites have gained the capacity to shift human rights petitions between domestic and regional scales to the forum that is most amenable to their interests. Second, ASEAN elites have situated the AICHR within the ASEAN Political-Security Community, ensuring that it unambiguously operates in the 'shadow of hierarchy' (Jessop 2011) by reporting to states' foreign ministers, and that, as the 'overarching' ASEAN rights body, the AICHR presides over related agencies, such as the ASEAN Commission on the Promotion and Protection of the Rights of Women and Children (ACWC). On the AICHR's depoliticizing impacts at the level of politics, the chapter highlights how the commission serves as the key regional target for claims from rights advocates, while not having the capacity to advance protections. Elites have sought to include rights advocates through two channels in the AICHR's processes, and both have been structured to include amenable interests and marginalize critics, limiting opportunities for rights advocates to contest policy or 
advance alternatives. The AICHR thus provides ASEAN elites with a tool to manage the conflicts that have arisen as a consequence of people's increased mobilization around human rights abuses.

The chapter first outlines the context for ASEAN's reform-namely, the Asian Economic Crisis, and the legitimacy crisis this generated for ASEAN and its members. The chapter then describes the role of the crisis in driving the mobilization of social movements organizing around conflicts arising from the predatory mode of capitalism that has characterized state management across the region in recent decades. Third, the chapter outlines ASEAN's human rights turn, highlighting how this issue was previously partitioned from regional governance, and its recent inclusion into ASEAN's activities as part of the institution's reform. Finally, the chapter charts how human rights governance has been reconfigured at the level of the polity and at the level of politics so as to address the conflicts presented by rights activists.

\subsection{Crises, Competing Interests, and Reform}

The drivers of ASEAN's reform have their roots in the Asian Economic Crisis that emerged in 1997. The crisis sparked domestic upheavals in affected countries, ignited by calls for greater accountability and transparency in governments. The most significant of these was the collapse of the Suharto regime in Indonesia after thirty 
years of rule. This occurred alongside the Reformasi movement in Malaysia that was led by the dismissed deputy prime minister Anwar Ibrahim; protests in Thailand that forced Chavalit Yongchaiyudh to resign, eventually making way for the rise of Thaksin Shinawatra, with his establishment of the Thai Rak Thai Party in 1998; while Joseph Estrada came to power in the Philippines in 1998, also winning by a wide margin on a populist platform. The economic and political effects of the crisis were, however, highly uneven across ASEAN states, and responses thus also varied. Elites in ASEAN's more developed countries pursued some social and political reforms so as to draw investors back to the region and restore domestic stability, with these reforms resisted by oligarchic forces. Meanwhile, ASEAN's newer members faced little imperative for reform because of the weakness of opposition forces in these countries (see Jones 2015, 2012).

For ASEAN, the economic crisis prompted a legitimacy crisis. The institution's conspicuous absence from the recovery, alongside the involvement of the International Monetary Fund (IMF) and the detrimental impacts of its policy prescriptions, prompted questions and criticisms regarding ASEAN's practices and purpose. ASEAN elites publicly acknowledged this legitimacy crisis, such as then secretary-general Rodolfo Severino, in a speech delivered at the University of Sydney on 22 October 1998: 
Today ... the overwhelming impression of East Asia's enduring strength and of ASEAN's efficacy has been cast aside and forgotten. The same commentators who used to assume a future of continuous growth for ASEAN now seem to believe that ASEAN can do nothing right — or can just do nothing. ... The frustration and bewilderment over the sudden reversal of fortunes of the region have led many, including some in Southeast Asia itself, to raise questions about ASEAN's effectiveness and utility and about the validity of the very idea of ASEAN. (Ahmad and Ghosal 1999: 759)

In the context of domestic political upheavals in some countries and widespread criticisms of ASEAN, its elites embarked on an ambitious reform programme. Central to this was the establishment of the ASEAN Economic Community, a single market that commenced at the end of 2015, intended to make the region more competitive for global capital flows.

This market-building programme was advanced by ASEAN's restructure in accordance with the regulatory transformations taking place in its member states. ASEAN's reform agenda reflected the transformations in state management that had begun in the late 1980s where 'good governance' directives increasingly shaped states' policies, with technocrats ever more involved in decision-making on the influence of leading development institutions, such as the World Bank. States' 
operations were increasingly characterized by new technocratic forms of government that were intended to enhance those institutions that aid markets, 'replacing politics with "good governance"” (Robison 2011: 9-10). The developmental state strategies that emerged in the postwar era were gradually superseded as states' new political projects were increasingly characterized by 'authoritarian liberalism', where a strong state apparatus is combined with a liberal market economy, and organized around regulatory modes of governance (Jayasuriya 2000: 19). Rather than directly intervening, the regulatory state functions as a facilitator or 'guardian of the market order', seeking to ensure market credibility (Jayasuriya 2003b: 205).

In accordance with this transformation in states' governance strategies, ASEAN was increasingly organized around a regulatory framework, seen through the various regulatory networks that have been established over the past decade. Through regulatory networks, states have harmonized standards and norms across the region, which have then been implemented and policed at the local level (Jayasuriya 2004, 2009). ASEAN's regulatory networks have not created the emergence of supranational authority. Instead, these networks that comprise representatives from state, private, and civil society entities have meant the 'rescaling of governance and policy making to regional spaces located within the state or alongside the established institutions of domestic rule' (Hameiri 2009: 431). These regional regulatory networks thus create spaces within states where actors are involved in regulating regional concerns. 
This regional regulatory framework is embodied in the networks that have been established across a widening set of issues - one example being the AICHR. Regulatory networks governing non-traditional security issues include the ASEAN Ministerial Meeting on Transnational Crime, the Regional Knowledge Network on Forest Law Enforcement and Governance, and the Regional Knowledge Network on Forests and Climate Change. These networks bring together representatives of the relevant state departments, research institutions, and civil society organizations to harmonize domestic rules and regulations. Similarly, in determining regional economic policy, the ASEAN Capital Market Forum brings together representatives from each member's securities commission to collaborate in harmonizing standards on capital market regulations.

Slaughter (2004) argues that networks of non-state actors can support governmental agencies in addressing the growing complexities of governance. However, this problem-solving approach to the inclusion of non-state actors in policymaking assumes that these different actors interact through networks in a nonconflicting manner, united by their pursuit of a common objective. Absent from this account is consideration of the politics that accompany network governance. In reflecting on the involvement of civil society organizations in policy networks, Peters and Pierre (2004) highlight the distribution of power in these processes, and the potential for policy decisions to be imposed rather than bargained for. They argue that 
the inclusion of a greater diversity of actors in policymaking can be a 'Faustian bargain', given that it creates the perception of inclusivity, serving to legitimate a policy outcome; however, the lack of rules governing the participation of lesspowerful actors means they have limited capacity to shape outcomes. In the case of ASEAN, Elliott notes: 'member states have instigated these arrangements to enhance their authority and the quality of formal rules. ASEAN policy-makers have made explicit strategic and political claims for the advantages of transgovernmental network arrangements' (2012: 49; emphasis in original). Elites have thus reconfigured political processes by establishing regulatory networks with the intention of increasing their influence and improving the efficacy of their activities. ASEAN's regulatory regional framework is thus entwined with the regulatory transformation taking place among members, and furthers elites' market-building programme by promoting the region's competitiveness.

This process of regional regulatory reform is not uncontested, given that rescaling the governance of an issue will privilege particular interests at the expense of others, and hence conflicts can arise as actors seek to control whether an issue is governed at the national, regional, or other scale (Hameiri and Jones 2012). These contestations are reflected in the highly partial and uneven process of liberalization that is taking place in developing the single market. This variegated process reflects the region's political economy and the conflicts that have emerged around the reconfiguring of this political 
project (Jones 2015). As outlined by Rodan et al. (2006), the process of state-led development in Southeast Asia has seen the fusing of the state and business interests, such that the latter have developed a vast influence over public policy. This degree of influence has meant that the attempt to make the region more globally competitive by liberalizing cross-border flows of goods, services, labour, and capital has been strongly contested by relevant coalitions, with their support or opposition determined by their potential to gain from this process. The process of liberalization has thus been highly variegated across sectors, with relevant coalitions competing across governance scales over how to organize the economy, and these struggles resulting in greater levels of economic integration in some contexts and not in others (Jones 2015). For example, on the movement of skilled professions, the establishment of a regional certification scheme for architects that permits movement across ASEAN states has emerged alongside a protectionist arrangement for medical professions. These differences in the regime governing labour movement reflect the political economy of each sector, where each country's bargaining position in developing a regional arrangement has been determined by whether the national bodies in each country had an interest in supporting professional labour migration (see Sumano 2013). The substantial influence of business interests in political processes arising from the region's state-led development has thus generated conflicts around the rescaling of 
sectoral governance, rendering integration through the ASEAN Economic Community highly uneven.

\subsection{ASEAN's Reform and Regional Activism}

The Asian Economic Crisis drove political mobilization against ASEAN's governments, clearly captured in the protests against the Suharto regime in Indonesia and the Reformasi movement in Malaysia. Demands for political participation by those whose fortunes were improved with the region's economic development saw the renewal of political activism in many states, albeit along agendas largely compatible with market reforms. Activism was detached from radical socio-political change and attempts to reform the structural sources of social inequality, instead centring on the protection of rights, liberty, and representative forms of government (Hewison and Rodan 2011: 25). Clammer (2003: 408) attributes this trend in Southeast Asia to the interweaving of civil society and state interests:

the problem of the civil society sector (non-governmental groups and institutions of a non-business nature) is both that its members are increasingly consumers and that the state that it is attempting to relate to is one increasingly pre-occupied with its own relationship to 
consumer capitalism ... made abundantly clear by the Asian currency crisis in 1997 and its social and economic fall-out.

Civil society organizations were nonetheless a crucial organizing force in the wake of the crisis, leading calls for greater transparency and accountability in governments and measures to address corruption. As noted by Ahmad and Ghosal: 'The shock of the crash prompted widespread challenges to the political and social status quo, with a bolder and better-educated middle class challenging the paternalistic order of the past' (1999: 767).

Activism was then increasingly regionalized in response to ASEAN's reform. People mobilized around ASEAN's politicization of issues that had typically been the purview of civil society organizations, such as those supporting human rights, workers' rights, and environmental protection, through the rescaling of the governance of these issues to the regional level. Groups began collaborating across countries, with their common experiences of organizing around issues arising from states' narrow pursuit of growth — such as land evictions, deforestation, child trafficking, and sex tourism - providing fertile ground for collaboration and the development of regional partnerships. Collaborating through networks permitted groups to pool resources - this being significant given the few resources with which these organizations frequently operate (Chong 2011). 
The regionalization of activism is evident in the establishment of regional networks and the development of ASEAN-focused activities in existing networks. Examples of networks that have been established solely to engage ASEAN or developed ASEAN-focused advocacy capacities (such as by having a staff member or 'desk' that organizes ASEAN campaigns) include the Southeast Asian Committee for Advocacy (SEACA), the Southeast Asia Women's Caucus on ASEAN, Asian Forum for Human Rights and Development (FORUM-ASIA), Asia Pacific Refugee Rights Network, Asian Partnership for the Development of Human Resources in Rural Asia (AsiaDHRRA), Focus on the Global South, Land Watch Asia, Child Rights Coalition, Migrant Forum in Asia, and the Alternative ASEAN Network on Burma (ALTSEANBurma). These networks often form an organizational umbrella under which national and local groups operate. They have been central in organizing opposition to ASEAN's market-building programme. Activities have taken numerous forms, including workshops, seminars and study tours, and the production and dissemination of information on the efficacy of advocacy efforts. For example, SEACA has published numerous edited volumes documenting advocacy in Southeast Asia, including Breaking Through: Political Space for Advocacy in South East Asia (Paredes et al. 2007). Regional networks have also produced and disseminated guides on how to engage ASEAN, such as FORUM-ASIA's handbooks designed to inform 
organizations of ASEAN policy, including Rights Now: A Training Manual on ASEAN Human Rights Mechanisms (FORUM-ASIA 2010).

The Solidarity for Asian People's Advocacy (SAPA) network was a crucial actor during the early stages of advocacy targeting ASEAN. It was established in 2006 in Bangkok with two aims: to promote campaigns on development issues in the region, and to advance civil society engagement with multilateral organizations (Dano 2008: 68). As suggested in its title, its activities cover the entire Asian region, and it is organized around three sub-regions — South Asia, Northeast Asia, and Southeast Asia—with working groups targeting the relevant multilateral processes for each subregion.

SAPA has been central to the organization of advocacy targeting ASEAN. Its significance has come from the willingness of the leaders of member organizations to pursue broad alliances, cutting across issues and countries (Ramirez 2008: 8). It has been central in the organization of the ASEAN Civil Society Conference, ${ }^{3}$ the main parallel summit for groups seeking to influence ASEAN (see Gerard 2013). By drawing on the research capacities of its various members, SAPA has been able to present a coherent alternative regional project, articulating a concerted position for an

${ }^{3}$ This forum has been held under various titles over its existence, including the 'ASEAN People's Forum' and the 'ASEAN Civil Society Conference/ASEAN People's Forum'. 
alternative regionalism that constitutes 'a counter-hegemonic challenge to the dominant ASEAN framework of conservatism, illiberal political governance and neoliberal economics' (Nesadurai 2011: 172). SAPA's structure has also been a central component of its success. The SAPA Working Group on ASEAN forms an organizational umbrella under which its various taskforces operate. For example, the SAPA Task Force on ASEAN and Human Rights formed in August 2007 as a means of uniting human rights groups to lobby ASEAN in the establishment of the AICHR. By bringing together organizations targeting specific ASEAN processes, with the taskforces then grouped under the banner of SAPA, the network has brought together the resources of its members in their attempts to influence ASEAN's political processes, creating alliances in what has historically been a highly atomized sector (see Rodan 2012).

\subsection{ASEAN's Human Rights Turn}

Human rights have historically been absent from debate and discussion in ASEAN forums. By invoking the non-interference norm, ASEAN elites have been able to confine the governance of human rights to the domestic scale, where conflicts have been more readily managed according to their interests. As demonstrated by Jones, the invoking of the non-interference norm in response to human rights abuses has 
occurred despite ASEAN elites' frequent interventions in one another's affairs. Rather than being a neutral commitment not to intervene in one another's domestic conflicts, the non-interference norm has never been absolute, having been used or ignored in accordance with the preferences of the region's dominant social forces to 'impose their interests as raison d'état' (Jones 2012: 2). ASEAN elites have intervened in one another's affairs since ASEAN's foundation, typically for the purpose of undermining political opponents and often with the support of Western powers. The 'Asian values' argument that was fervently promoted in the 1990s by Malaysian Prime Minister Mahathir Mohamad and Singaporean Prime Minister Lee Kuan Yew similarly functioned in confining human rights conflicts to the domestic scale by challenging the notion that human rights are universal. Proponents of 'Asian values' argued that human rights were shaped by a country's experience, challenging the universalism of human rights and legitimating non-democratic leadership.

In a radical shift and as part of ASEAN's reform, human rights governance was rescaled to the regional arena. The ASEAN Charter, ratified in November 2007, included a commitment to establish a regional human rights agency. A high-level panel was formed in July 2008 and tasked with drafting the agency's terms of reference, which were ratified in July 2009. In October 2009, the first commissioners to the AICHR were appointed, with one representative from each state. The AICHR then developed the ASEAN Human Rights Declaration (henceforth the declaration), 
adopting the terms of reference for the drafting group at its fifth meeting, in April 2011. The drafting group met for the first time in July 2011, and submitted a basic draft to the AICHR in January 2012. Following negotiations, the declaration was then ratified on 18 November 2012. While the declaration is not a legally binding treaty, such instruments are often precursors to binding treaties, and they can also carry significant moral weight, such as in the case of the 1948 Universal Declaration on Human Rights (Gerber 2012).

The ASEAN declaration has been widely criticized for its various loopholes. The SAPA Task Force on ASEAN and Human Rights has termed these flaws 'ready made justifications' for human rights violations (SAPA TFAHR 2013: 38). For example, Principle 6 states: 'The enjoyment of human rights and fundamental freedoms must be balanced with the performance of corresponding duties as every person has responsibilities to all other individuals, the community and the society where one lives' (ASEAN 2012). As noted by Gerber (2012):

This implies that the enjoyment of human rights is conditional upon individuals being 'good' citizens. This is inconsistent with international human rights norms which mandate that upholding an individual's human rights is not dependent upon them being responsible members of society; even prisoners and terrorists have human rights. 
ASEAN elites sought to allay critics, justifying the declaration's limitations by pointing to the differences across member states and the subsequent difficulties of achieving consensus, particularly where the norm of consensus decision-making gives a single state veto power. For example, Director General of ASEAN Cooperation at the Indonesian Foreign Ministry, I Gusti Agung Wesaka Puja, argued: 'It is not easy to unify 10 nations and reach a similar level of protection' (Santosa and Ririhena 2012). ASEAN elites also highlighted the significance of the document in the institution's history, and its 'evolutionary' capacity, as noted by former Thai Prime Minister Abhisit Vejjajiva, who described the AICHR as 'a significant milestone in the evolution of ASEAN' and an 'evolutionary process toward strengthening the human rights architecture in the region' (Jakarta Post 2009). However, rather than understanding the AICHR as a 'work in progress', thereby assuming that the establishment of this agency will lead to the expansion of rights protections, section 6.5 charts how human rights governance has been reconfigured across the levels of the polity and politics, and the impacts of this process.

\subsection{The ASEAN Intergovernmental Commission on}

\section{Human Rights}


With the commitment in the ASEAN Charter to establish a regional human rights agency, human rights governance was politicized because the 'lines of difference' regarding what is considered a political issue for the institution were redrawn to include human rights (Jessop 2014). However, the rescaling of governance through the AICHR has had a depoliticizing impact, given that the context in which politics takes place has been altered such that the AICHR's processes favour the interests of ASEAN elites at the expense of human rights activists.

The AICHR's depoliticizing impacts on the level of the polity lie, first, in the potential for human rights abuses to be rescaled according to the interests of ASEAN elites. This potential comes from the absence of a clearly delineated relationship between the AICHR and domestic political agencies, specifically the National Human Rights Institutions. ${ }^{4}$ The ASEAN Charter that entered into force in December 2008 included a commitment to establish a regional human rights body, despite not all

${ }^{4}$ National human rights institutions were established in Indonesia, Thailand, and Malaysia in 1993, 1997, and 1999, respectively. These existed alongside the Philippine National Human Rights Institution, established with the constitutional changes of the late 1980s that followed the fall of President Ferdinand Marcos. As part of recent political reforms, Myanmar established the National Human Rights Commission in September 2011, and the Cambodian Government similarly established a human rights committee in 2006 and has indicated its support for establishing a national human rights institution. 
member states having established national human rights institutions by this time. The AICHR's terms of reference do not specify its relationship to the national human rights institutions, noting only that it can 'consult, as may be appropriate with other national, regional and international institutions and entities concerned with the promotion and protection of human rights' (AICHR 2009). The absence of delineated powers between these agencies means that the governance scale for human rights abuses - each with their own set of actors, resources, and political opportunities - is determined not by human rights advocates or petitioners but by ASEAN elites, specifically AICHR representatives and appointees in those national human rights institutions that exist in six of ASEAN's ten member states. This creates the potential for ASEAN elites to rescale the governance of cases to the forum that is most beneficial for their interests. Human rights advocates have sent petitions to the AICHR and the national human rights institutions, described below; however, the lack of specification regarding the relationship between these national and regional entities means there is no defined process through which a case progresses. The ambiguity regarding the appropriate forum for human rights governance means the actors within these agencies are the ones who determine the course of action, rather than advocates or petitioners, with no procedural constraints that advance human rights protections. A related depoliticizing impact of the AICHR at the level of the polity is its institutional 'home' within ASEAN. The AICHR's remit aligns with the ASEAN 
Socio-Cultural Community, and its mandate and activities overlap with agencies located in this 'pillar' - notably, the ACWC. Despite these alignments, the AICHR has been located within a different 'pillar': the ASEAN Political-Security Community. The AICHR consequently reports to the ASEAN foreign ministers, thereby configuring regional human rights governance as related to the concerns of state foreign departments - typically security and trade issues — rather than the social and welfare concerns of the ASEAN Socio-Cultural Community and related state departments. The ACWC, situated in the ASEAN Socio-Cultural Community, submits its report of annual activities to the ASEAN Ministers' Meeting on Social Welfare and Development, the ASEAN Committee on Women, and other relevant sectoral bodies (ACWC 2009). Locating the AICHR within the ASEAN Political-Security Community limits the capacity of its representatives to advance more radical proposals by ensuring that this agency can be readily steered according to the preferences of ASEAN elites. Moreover, the AICHR's terms of reference describe it as the 'overarching' agency for human rights in ASEAN, indicating that its decisions and processes subsume the activities of other ASEAN rights agencies, including the ACWC. This positioning of the AICHR as ASEAN's principal rights agency creates the capacity for ASEAN elites to similarly steer the activities of other rights agencies. Locating the AICHR within the Political-Security Community rather than the SocioCultural Community ensures that it unquestionably operates in the 'shadow of 
hierarchy', and its positioning as ASEAN's overarching rights agency constrains the scope for more substantive rights protections through other agencies. These two characteristics at the policy level highlight how, through the establishment of the AICHR, human rights governance has empowered ASEAN elites.

On the AICHR's depoliticizing impacts at the level of politics, the two channels through which ASEAN elites have included rights advocates have been structured to include amenable interests and to marginalize critics, limiting opportunities for rights advocates to contest policy or advance alternatives. ASEAN elites claimed regional integration would be an inclusive process (see Gerard 2014), and the involvement of rights advocates in the AICHR has taken two forms: the nomination of activists as state representatives for the AICHR, and consultations with rights activists during the drafting of the declaration. On the former, the AICHR comprises one representative from each member state. State representatives are either appointed by states or, in the case of Indonesia and Thailand, selected by a committee. The majority of representatives are drawn from state departments. For example, the Malaysian AICHR representative, Tan Sri Muhammad Shafee Abdullah, served three terms as commissioner of the Malaysian National Human Rights Institution (SUHAKAM) prior to his appointment as the Malaysian representative in the AICHR. Similarly, the Cambodian AICHR representative, Om Yentieng, was a member and president of the Cambodian Human Rights Committee. 
The selection of representatives who advance the interests of ASEAN elites is clearly demonstrated in the case of Malaysian AICHR representative, Tan Sri Muhammad Shafee Abdullah. Shafee is the personal lawyer of Malaysian Prime Minister Najib Razak and has close links with the ruling party. He was appointed to the AICHR in 2009 and reappointed for a second term in 2013. Human rights advocates requested that Shafee step down from the AICHR in light of his decision to act as counsel for the state government of Negri Sembilan in its appeal against crossdressing. Rights advocates argued Shafee is violating human rights by supporting the state government in its bid to appeal against an appellate court ruling that the state's sharia enactment punishing transgender citizens for cross-dressing was unconstitutional. Yap Swee Seng, the Executive Director of Malaysian human rights organization Suaram, argued: 'If he is going to act as [an AICHR] commissioner, he should be playing the role of the human rights defender. By acting for the government ... he is acting against the rights of the transgenders' (Shukry 2014). Shafee's human rights track record has also been criticized on the grounds that he served as prosecutor in the sodomy trial against former deputy prime minister Anwar Ibrahim. Shafee's appointment highlights the significant scope for ASEAN elites to nominate representatives who advance the interests of specific coalitions, and undermine human rights protections. 
The Indonesian and Thai practice of a selection committee appointing representatives has created some diversity in the AICHR, such that it comprises one academic and one activist. Former Thai representative, Dr Sriprapha Petcharamesree, is a former faculty member at Mahidol University and director of its Office of Human Rights Studies and Social Development. Petcharamesree sat alongside Rafendi Djamin, director of a coalition of Indonesian human rights organizations. Both appointments were conducted through an open selection process, where a selection committee comprising state and civil society representatives selected from a pool of candidates nominated by the public. For example, in the case of Rafendi Djamin's 2013 reappointment, the selection team comprised representatives from the Ministry of Law and Human Rights, the Indonesian Human Rights National Commission (KOMNAS HAM), the Ministry of Foreign Affairs, and one journalist (AICHR 2013).

Through the selection process conducted by Indonesia and Thailand, openings have been created for rights activists to participate in the AICHR. However, the capacity for these individuals to exert influence over the agency's activities is impeded by their marginal role, given the invoking of consensus decision-making that ensures that the recommendations of critics can be readily blocked. Additionally, despite the public nomination process, these individuals are still decided by ASEAN elites. This method of widening representation in the AICHR thus has limited potential for advancing rights protections. 
The second means through which ASEAN elites engaged rights activists in the AICHR is by holding consultations with civil society organizations during the drafting of the declaration. In response to concerns from the International Commission of Jurists (ICJ), Amnesty International, and the United Nations Office of the High Commissioner for Human Rights (OHCHR) regarding the secrecy of negotiations for the declaration, the AICHR denied it was operating in secrecy and announced it would hold two regional consultations with civil society organizations. AICHR representatives then agreed at their June 2012 meeting in Yangon that each would select four organizations to invite to a consultation, with each organization sending two representatives (Wahyuningrum 2012). A second consultation was held on 12 September 2012, in Kuala Lumpur, governed by the same rules determining which organizations could participate. Through this process, ASEAN elites steered these consultations according to their preferences, managing activists' access so as to include amenable groups and marginalize critical ones. The reconfiguring of human rights governance through the AICHR has thus provided ASEAN elites with a tool to manage the conflicts that have arisen as a consequence of people's increased mobilization around human rights abuses.

These depoliticizing impacts of the AICHR are demonstrated in the case of the disappearance of Laotian environmental activist and founder and former director of the Participatory Development Training Centre in Lao PDR, Sombath Somphone. The 
AICHR is not mandated to investigate complaints regarding specific human rights violations. While initially refusing to receive petitions from rights advocates, the agency now accepts them via email, the online query function on the AICHR website, and the ASEAN Secretariat. The chair of the AICHR, which rotates annually in accordance with the ASEAN chairmanship, circulates petitions to representatives (FORUM-ASIA 2013). However, there are no requirements for the AICHR to discuss these petitions at meetings or respond to petitioners. ${ }^{5}$

Since the AICHR's establishment, rights advocates have submitted six petitions, one of these regarding the disappearance of Sombath. Just prior to his disappearance in December 2012, he was co-chair of the Lao National Organizing Committee for the Asia-Europe People's Forum, held in October 2012, where a number of critics spoke out against human rights abuses in Lao PDR. On the evening of 15 December 2012, closed-circuit television (CCTV) footage showed Sombath being stopped at a police checkpoint, walking towards the police officers stationed there, and then getting into a pickup truck and being driven away, followed by two motorcyclists; Sombath has not been seen since (ICJ 2014). Ng Shui Meng, his partner, filed a missing person's report

\footnotetext{
${ }^{5}$ The AICHR sent a letter acknowledging receipt of the petition sent by the Makassar Legal
} Aid Institute concerning the assault on the Ahmadiyya Muslim Community in South Sulawesi; however, it has not responded in a more substantive fashion (FORUM-Asia 2014). 
the following day. The police have not released the CCTV footage showing Sombath's last recorded movements; however, they showed it to $\mathrm{Ng}$ Shui Meng, who recorded it on her phone and later uploaded it to YouTube, enabling the event to attract attention from rights advocates across the globe.

The Lao Government responded to the missing persons report and public calls for an investigation by issuing four statements and three reports, all of which deny state involvement in Sombath's disappearance. These reports state that Sombath's disappearance can be attributed to a 'personal conflict or a conflict in business', and note that no-one could be identified from the CCTV footage, nor were there any unusual incidents reported at the checkpoint on the night in question (ICJ 2014: 5). The police also rejected an offer of assistance from the United States Embassy in conducting the investigation. Based on their assessment, the ICJ (2014: 6) asserted, 'there are reasonable grounds to believe that Sombath Somphone was the victim of an enforced disappearance'.

Regional rights advocates first submitted a petition to the AICHR on this case on 4 January 2013, with follow-up letters sent on 1 February 2013 and 26 April 2013. This high-profile case drew criticism from regional and international rights organizations, foreign governments, and regional and global institutions, with letters 
of concern sent by the ICJ, Amnesty International, the European Union, the Australian Senate, the UK Foreign Office, and the OHCHR, among others. ${ }^{6}$

Following the petitions sent by FORUM-Asia and the calls for action from across the globe, the AICHR reportedly discussed this case at a meeting in Brunei in March 2013; however, publicly it remained silent on the issue (Wahyuningrum 2014). The ASEAN Summit in April 2013 noted this incident was to be discussed under the agenda of the AICHR; however, there was a lack of consensus in raising the item at the summit and it was later dropped (Constant 2013). Indonesia, the Philippines, Thailand, and Myanmar are reportedly supportive of the AICHR using its mandate to obtain information from the Lao Government, as detailed in 4.1 of its terms of reference (Chongkittavorn 2014). However, other members invoking the norms of consensus and non-interference have functioned to ensure the AICHR cannot advance human rights protections. The establishment of the AICHR thus enables ASEAN elites to assert they are working to expand human rights protections, while this agency is structured such that it cannot achieve this objective.

\footnotetext{
${ }^{6}$ For a full listing, see http://sombath.org/global-concern/statements.
} 


\subsection{Conclusion: Restructuring, and Depoliticizing,}

\section{Regional Governance}

The project of reforming ASEAN that has been underway for the past two decades has entailed the vertical expansion of its political processes, with new spaces of regional governance created within state apparatuses where networks harmonize standards and seek to implement them at the domestic scale. It has also involved the horizontal expansion of its political processes, through the increased diversity of actors engaged in its regulatory networks, with these coming from state agencies, civil society organizations, think tanks, academia, and scientific communities.

Through the lens of the AICHR, this chapter has examined the impacts of this reconfiguration of political processes. ASEAN elites' rhetoric regarding 'communitybuilding' and 'people-oriented reforms' suggests that ASEAN's transformation challenges its legacy of anti-politics. However, in the case of the AICHR, the depoliticizing impacts of these processes have occurred at the level of the polity and at the level of politics, enabling the AICHR to function so that it empowers elites as opposed to rights advocates. The AICHR thus continues ASEAN's legacy of antipolitics, not by taking the politics out of human rights governance, but by enabling ASEAN elites to manage conflicts over human rights abuses according to their preferences. 
The AICHR's depoliticizing impacts are evident at the level of the polity in, first, its undefined relationship to national human rights institutions, which enables ASEAN elites to shift petitions to the governance scale that is most amenable to their interests; and second, through the AICHR's location within the Political-Security Community rather than the more relevant Socio-Cultural Community, which ensures this agency can be readily steered by states' foreign ministries rather than by potentially more transformative actors within states' social and welfare departments. Furthermore, the AICHR's positioning as the 'overarching' ASEAN rights agency curbs the potential for other agencies to be more active in expanding rights protections. Its depoliticizing impacts at the level of politics are demonstrated through strategies to simultaneously include a wider set of interests in human rights governance, while limiting their scope to contest policy or advance alternatives. These impacts at the level of politics can be observed in the appointment of rights activists as state representatives to the AICHR, while limiting their capacity to advance rights protections by invoking the norms of non-interference and consensus decision-making. Similarly, the agency's constrained consultations with rights activists on the drafting of the declaration such that they were unable to change its content saw these consultations legitimize the AICHR's procedures and the declaration, while marginalizing the conflicts around which activists had organized. 
The reconfiguring of political processes through the establishment of the AICHR has thus provided ASEAN elites with a tool to manage the conflicts that have emerged from people's increased mobilization around human rights abuses. Thus, despite the rhetorical shift towards inclusion and community in the marketing of ASEAN's reform, the AICHR's depoliticizing impacts suggest that this political project remains calibrated towards the defence of powerful interests.

\section{References}

Ahmad, Z. H., and B. Ghosal, 1999. 'The Political Future of ASEAN after the Asian Crisis'. International Affairs 75(4): 759-78.

ASEAN Commission for the Promotion and Protection of the Rights of Women and Children (ACWC), 2009. Terms of Reference of the ASEAN Commission for the Promotion and Protection of the Rights of Women and Children, Jakarta: ASEAN Secretariat.

ASEAN Intergovernmental Commission on Human Rights (AICHR), 2009. Terms of Reference of ASEAN Intergovernmental Commission on Human Rights, Jakarta: ASEAN Secretariat.

http://aichr.org/about/?doing_wp_cron=1370402870.8765289783477783203125. ASEAN Intergovernmental Commission on Human Rights (AICHR). 2012. ASEAN Human Rights Declaration, Jakarta: ASEAN Secretariat. http://aichr.org/documents/. 
ASEAN Intergovernmental Commission on Human Rights (AICHR), 2013.

Reappointment of Mr Rafendi Djamin as Indonesian Representative for the AICHR. Press release, 4 January, AICHR, Jakarta. http://aichr.org/pressrelease/re-appointment-of-mr-rafendi-djamin-as-indonesian-representative-for-theasean-intergovernmental-commission-on-human-rights-aichr.

Asian Forum for Human Rights and Development (FORUM-ASIA), 2010. Rights Now: A Training Manual on ASEAN Human Rights Mechanisms. Bangkok: FORUM-ASIA. http://www.forum-asia.org/?p=5551.

Asian Forum for Human Rights and Development (FORUM-ASIA), 2013. 'ASEAN Intergovernmental Commission on Human Rights: About'. Human Rights in ASEAN: Online Platform. http://humanrightsinasean.info/aseanintergovernmental-comission-human-rights/about.html.

Asian Forum for Human Rights and Development (FORUM-ASIA), 2014. 'ASEAN Intergovernmental Commission on Human Rights: Complaints'. Human Rights in ASEAN; Online Platform. https://humanrightsinasean.info/aseanintergovernmental-commission-human-rights/submissions-aichr.html.

Aviel, J. F., 2000. 'Placing Human Rights and Environmental Issues on ASEAN's Agenda: The Role of Non-governmental Organizations'. Asian Journal of Political Science 8(2): 17-35. 
Chong, T., 2011. 'Executive Summary'. In An ASEAN Community for All: Exploring the Scope for Civil Society Engagement, eds T. Chong and S. Elies, pp. 9-20. Singapore: Frederich-Ebert-Stiftung.

Chongkittavorn, K., 2014. 'AICHR Can Do More to Protect ASEAN Citizens'. The Nation, 28 April. http://www.nationmultimedia.com/homeAICHR-can-do-moreto-protect-Asean-citizens-30232324.html.

Clammer, J., 2003. 'Globalisation, Class, Consumption and Civil Society in Southeast Asian Cities'. Urban Studies 40(2): 403-19.

Constant, M., 2013. 'Activist's Disappearance Gives Vientiane a Black Eye in ASEAN'. Bangkok Post, 16 June.

http://www.bangkokpost.com/news/investigation/355334/activist-disappearancegives-vientiane-a-black-eye-in-asean.

Dano, E. 2008. Building People-Oriented and Participatory Alternative Regionalism Models in Southeast Asia, Manila \& Bangkok: Asian Farmers Association for Sustainable Rural Development and AsiaDHRRA.

http://asiadhrra.org/wordpress/wpcontent/uploads/2008/03/alternative_regionalism.pdf.

Davies, M., 2013a. 'ASEAN and Human Rights Norms: Constructivism, Rational Choice, and the Action-Identity Gap'. International Relations of the Asia Pacific 13: 207-31. 
Davies, M., 2013b. 'Explaining the Vientiane Action Programme: ASEAN and the Institutionalization of Human Rights'. The Pacific Review 26(4): 385-406.

Durbach, A., C. Renshaw, and A. Byrnes, 2009. ““A Tongue But No Teeth?”: The Emergence of a Regional Human Rights Mechanism in the Asia Pacific Region'. Sydney Law Review 31: 211-38.

Elliott, L., 2012. 'ASEAN and Environmental Governance: Strategies of Regionalism in Southeast Asia'. Global Environmental Politics 12(3): 38-57.

Fawcett, P., and D. Marsh, 2014. 'Depoliticisation, Governance and Political Participation'. Policy \& Politics 42(2): 171-88.

Flinders, M., and J. Buller, 2006. 'Depoliticisation: Principles, Tactics and Tools'. British Politics 1: 293-318.

Gerard, K., 2013. 'From the ASEAN People's Assembly to the ASEAN Civil Society Conference: The Boundaries of Civil Society Advocacy'. Contemporary Politics 19(4): 411-26.

Gerard, K., 2014. 'ASEAN and Civil Society Activities in "Created Spaces": The Limits of Liberty'. The Pacific Review 27(2): 265-87.

Gerber, P., 2012. 'ASEAN Human Rights Declaration: A Step Forward or a Slide Backwards?'. The Conversation, 21 November. http://theconversation.com/aseanhuman-rights-declaration-a-step-forward-or-a-slide-backwards-10895. 
Ginbar, Y., 2010. 'Human Rights in ASEAN - Setting Sail or Treading Water?' Human Rights Law Review 10(3): 504-18.

Hameiri, S., 2009. 'Beyond Methodological Nationalism, But Where to for the Study of Regional Governance?'. Australian Journal of International Affairs 63(3): 43041.

Hameiri, S., and L. Jones, 2012. 'The Politics and Governance of Non-traditional Security'. International Studies Quarterly 57(3): 462-73.

Hewison, K., and G. Rodan, 2011. 'Southeast Asia: The Left and the Rise of Bourgeois Opposition'. In Routledge Handbook of Southeast Asian Politics, ed. R. Robison, pp. 25-39. Abingdon, UK: Routledge.

International Commission of Jurists (ICJ), 2014. Missed Opportunities:

Recommendations for Investigating the Disappearance of Sombath Somphone, Geneva: International Commission of Jurists.

Jakarta Post, 2009. 'Southeast Asia Launches Human Rights Body'. The Jakarta Post, 23 October. http://www.thejakartapost.com/news/2009/10/23/southeast-asialaunches-human-rights-body.html.

Jayasuriya, K., 2000. 'Authoritarian Liberalism, Governance, and the Emergence of the Regulatory State in Post-crisis East Asia'. In Politics and Markets in the Wake of the Crisis, eds R. Robison, M. Beeson, K. Jayasuriya, and H.-R. Kim, pp. 31530. London \& New York: Routledge. 
Jayasuriya, K., 2003. 'Introduction: Governing the Asia Pacific_-Beyond the "New Regionalism"”. Third World Quarterly 24(2): 199-215.

Jayasuriya, K., 2004. 'Introduction: The Vicissitudes of Asian Regional Governance'. In Asian Regional Governance: Crisis and Change, ed. K. Jayasuriya, pp. 1-18. London: Routledge Curzon.

Jayasuriya, K., 2009. 'Regulatory Regionalism in the Asia-Pacific: Drivers, Instruments and Actors'. Australian Journal of International Affairs 63(3): 33547.

Jessop, B., 2011. 'Metagovernance'. In The SAGE Handbook of Governance, ed. M. Bevir, pp. 106-23. London: Sage.

Jessop, B., 2014. 'Repoliticising Depoliticisation: Theoretical Preliminaries on Some Responses to the American Fiscal and Eurozone Debt Crises'. Policy \& Politics 42(2): 207-23.

Jones, L., 2012. ASEAN, Sovereignty and Intervention in Southeast Asia, New York: Palgrave Macmillan.

Jones, L., 2015. 'Explaining the Failure of the ASEAN Economic Community: The Primacy of Domestic Political Economy'. The Pacific Review 19: 1-24.

Katsumata, H., 2009. 'ASEAN and Human Rights: Resisting Western Pressure or Emulating the West?'. The Pacific Review 22(5): 619-37. 
Krook, M. L, and J. True, 2012. 'Rethinking the Life Cycles of International Norms: The United Nations and the Global Promotion of Gender Equality'. European Journal of International Relations 18(1): 103-27.

Lasswell, H., 1936. Politics: Who Gets What, When and How, New York: Meridian.

Narine, S., 2012. 'Human Rights Norms and the Evolution of ASEAN: Moving Without Moving in a Changing Regional Environment'. Contemporary Southeast Asia 34(3): 365-88.

Nesadurai, H., 2011. 'The ASEAN People's Forum (APF) as Authentic Social Forum: Regional Civil Society Networking for an Alternative Regionalism'. In Routledge Handbook of Asian Regionalism, eds M. Beeson and R. Stubbs, pp. 166-76. Oxford: Routledge.

Paredes, J., M. de Guzman, and E. Rillorta (eds), 2007. Breaking Through: Political Space for Advocacy in Southeast Asia, Manila: South East Asian Committee for Advocacy.

Peters, B. G., and J. Pierre, 2004. 'Multi-Level Governance and Democracy: A Faustian Bargain?'. In Multi-Level Governance, eds I. Bache and M. Flinders, pp. 75-92. Oxford: Oxford University Press.

Ramirez, M., 2008. AsiaDHRRA and ASEAN: A Case Study of the Process of Civil Society Engagement with a Regional Intergovernmental Organisation. Paper presented at the FIM Forum, Montreal, 8-9 February. 
Robison, R., 2011. 'Interpreting the Politics of Southeast Asia: Debates in Parallel Universes'. In Routledge Handbook of Southeast Asian Politics, ed. R. Robison, pp. 5-22. Abingdon, UK: Routledge.

Rodan, G., 2012. 'Competing Ideologies of Political Representation in Southeast Asia'. Third World Quarterly 33(2): 311-32.

Rodan, G., K. Hewison, and R. Robison, 2006. 'Theorising Markets in Southeast Asia: Power and Contestation'. In The Political Economy of Southeast Asia: Markets, Power and Contestation, eds G. Rodan, K. Hewison, and R. Robison, pp. 1-38. Oxford: Oxford University Press.

Santosa, N. I., and Y. Ririhena, 2012. 'ASEAN Leaders Adopt Lame-Duck Agreement'. The Jakarta Post, 19 November. http://www.thejakartapost.com/news/2012/11/19/asean-leaders-adopt-lame-duckrights-declaration.html.

Shukry, A., 2014. 'Step Down as Malaysia’s Human Rights Rep, Groups Tell UMNO Lawyer Shafee'. The Malaysia Insider, 24 December. http://www.themalaysianinsider.com/malaysia/article/step-down-as-malaysiashuman-rights-rep-groups-tell-umno-lawyer-shafee.

Slaughter, A.-M., 2004. A New World Order, Princeton, NJ: Princeton University Press. 
Solidarity for Asian's People Advocacy Task Force on ASEAN and Human Rights (SAPA TFAHR), 2013. Still Window Dressing: A Performance Report on the Third Year of the ASEAN Intergovernmental Commission on Human Rights (AICHR) 2011-2012, Bangkok: Asian Forum for Human Rights and Development.

Sumano, B., 2013. Explaining the Liberalisation of Professional Migration in ASEAN. PhD thesis, School of Politics and International Relations, University of London, London.

Tan, H.-L., 2011. The ASEAN Intergovernmental Commission on Human Rights: Institutionalising Human Rights in Southeast Asia, Cambridge: Cambridge University Press.

Wahyuningrum, Y., 2012. Notes on the Process of the 2nd Regional Consultation on AHRD, Kuala Lumpur. ASEANCats Google Group, 22 June.

Wahyuningrum, Y., 2014. 'AICHR After Five Years: Progress, Challenges and Opportunities'. Focus 76, Osaka: Asia Pacific Human Rights Information Center. http://www.hurights.or.jp/archives/focus/section3/2014/06/aichr-after-five-yearsprogress-challenges-and-opportunities.html. 